НАУКОВИЙ ВІСНИК

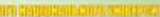

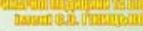

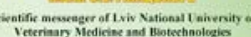

7

9uw wosk

TIIH

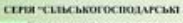
Tov 21 Nig 90

2019
Науковий вісник Львівського національного університету ветеринарної медицини та біотехнологій імені С.3. Гжицького. Серія: Сільськогосподарські науки

Scientific Messenger of Lviv National University of Veterinary Medicine and Biotechnologies.

Series: Agricultural sciences

UDC 636.087 .7

\title{
Estimation of efficiency of application of technological feed supplement of hepasorbex in vitro
}

\author{
T.R. Levytskyy
}

State Scientific-Research Control Institute of Veterinary Medicinal Products and Feed Additives, Lviv, Ukraine

Article info

Received 04.02.2019

Received in revised form 06.03 .2019

Accepted 07.03.2019

State Scientific-Research Control Institute of Veterinary Medicinal Products and Feed Additives, Donetska Str.,11, Lviv, 79019, Ukraine. Tel.: +38-067-670-63-07 E-mail: taraslev@i.ua
Levytskyy, T.R. (2019). Estimation of efficiency of application of technological feed supplement of hepasorbex in vitro. Scientific Messenger of Lviv National University of Veterinary Medicine and Biotechnologies. Series: Agricultural sciences, 21(90), 49-53. doi: 10.32718/nvlvet-a9008

The study of the effectiveness of the application of the technological feed additive Hepasorbex from the functional group of substance in order to reduce the contamination of feed with mycotoxins in laboratory conditions has been carried out. The aim of the work was to establish in vitro the effectiveness of the use of the feed supplements Hepasorbex by confirming its ability to inhibit or reduce the absorption of mycotoxin aflatoxin $B_{1}$. The effectiveness of the specific action of the feed additive was determined quantitatively at different $\mathrm{pH}$ values simulating changes in the acidity of environment in the digestive tract of animals. The study was conducted in two stages: screening - using the solution of mycotoxin and the main - using a forage containing mycotoxin. The feed supplement Hepasorbex was introduced into a buffer solution containing Aflatoxin $B_{1}$ in an amount of $200 \mu \mathrm{g} / \mathrm{ml}$ at the screening stage. The investigated feed supplement Hepasorbex was introduced into samples of compound feed containing Aflatoxin $B_{I}$ at a rate of $1,2,5 \mathrm{~g} / \mathrm{kg}$ and carefully homogenized samples in the main experiment. The determination of adsorption (in acidic medium) and desorption (in alkaline medium) was carried out. The criterion for evaluating the effectiveness was the practical efficiency, which was calculated by establishing the difference between the amount of mycotoxin introduced in the buffer solution or the amount of mycotoxin found in feed and the amount of adsorbed mycotoxin after incubation in the acidic environment, taking into account the size of the desorption after incubation in alkaline environment. It was established that in the screening studies, the practical factor of the beneficial effect of the feed supplement on Aflatoxin B1 was $89.5 \%$. It was found in the main study that the practical benefit factor of the feed supplement, depending on the dose, was 75.0-84.4\%. The obtained results confirm that the investigated feed additive possesses clear adsorption properties in relation to aflatoxin $B_{1}$.

Key words: aflatoxin, adsorption, desorption, mycotoxins.

\section{Оцінка ефективності застосування технологічної кормової добавки Гепасорбекс in vitro}

\author{
Т.Р. Левицький
}

Державний науково-дослідний контрольний інститут ветеринарних препаратів та кормових добавок, м. Львів, Україна

\footnotetext{
Проведено вивчення ефективності застосування технологічної кормової добавки Гепасорбекс із функціональної групи речовини для зменшення забруднення кормів мікотоксинами в лабораторних умовах. Метою роботи було встановлення іп vіtro ефективності застосування кормової добавки Гепасорбекс иляхом підтвердження ї̈ здатності стримувати або знижувати поглинання мікотоксину афлатоксин $B_{l}$. Ефективність специфічної дї кормової добавки визначали кількісно при різних значеннях рН, щзо імітують зміну кислотності середовища в травному каналі тварин. Дослідження проведено у два етапи: скринінговий - з використанням розчину мікотоксину та основний - з використанням комбікорму, який містив мікотоксин. На скринінговому етапі кормову добавку Гепасорбекс вносили у буферний розчин, який містив афлатоксин В, у кількості 200 мкг/мл. В основному досліді досліджувану кормову добавку Гепасорбекс вносили у зразки комбікормів, які містили афлатоксин $B_{1}$, 3 розрахунку 1,2 , 5 г/кг $i$
} 
ретельно гомогенізували проби. Проведено визначення величини адсорбиії (в кислому середовищі) та величину десорбції (в лужному середовищі). Критерієм оцінки ефективності був практичний коефіцієнт корисної дї, який обраховувався шляхом встановлення різниці між кількістю внесеного у буферний розчин або виявленого у комбікормі мікотоксину та кількістю адсорбованого мікотоксину після інкубації у кислому середовищі з врахуванням величини десорбції після інкубації у лужному середовищі. Встановлено, щзо при скринінгових дослідженнях практичний коефічієнт корисної дї кормової добавки стосовно афлатоксину В 89,5\%. В основному досліді виявлено, щзо практичний коефіцієнт корисної дї кормової добавки залежно від дози становив 75,0 84,4\%. Отримані результати підтверджують те, щуо досліджувана кормова добавка володіє вираженими адсорбиійними властивостями стосовно афлатоксину $B_{l}$.

Ключові слова: афлатоксин, адсорбиія, десорбиія, мікотоксини

\section{Вступ}

Проблема забруднення кормів мікотоксинами залишається актуальною вже протягом багатьох років. Тваринницький бізнес зазнає значних втрат через зниження продуктивності та виникнення захворювань які пов'язані з наявністю мікотоксинів у кормах. Тому постійно тривають пошуки шляхів зниження або усунення негативного впливу мікотоксинів на організм тварин. Внесення у корми добавок, які усувають негативну дію мікотоксинів, є перспективним напрямком досліджень. Промислове виробництво продукції тваринництва на даному етапі не обходиться без використання кормових добавок. У Законі України "Про безпечність та гігієну кормів” встановлено чітке визначення поняття кормові добавки - це речовини, мікроорганізми або суміші, інакші, ніж кормовий матеріал або премікси, які спеціально додаються до корму або води з метою виконання однієї чи декількох 3 таких функцій: задоволення поживних потреб тварин, забезпечення сприятливого впливу на характеристики кормів, продуктів тваринного походження, екологічних наслідків тваринницької діяльності, продуктивність та благополуччя тварин, зокрема шляхом впливу на шлунково-кишкову флору та засвоюваність кормів чи колір декоративних рибок та птахів, здійснення кокцидіостатичної чи гістомоностатичної дії. Кормові добавки поділяються на п'ять категорій. У межах відповідної категорії кормова добавка може бути віднесена до однієї або декількох функціональних груп. Для усунення негативного впливу мікотоксинів використовують кормові добавки із категорії технологічні добавки, які належать до функціональної групи речовин для зменшення забруднення кормів мікотоксинами - речовини, здатні стримувати або знижувати поглинання мікотоксинів, сприяти їх виведенню чи змінювати спосіб їх дії (Zakon Ukrayiny' "Pro bezpeku ta gigiyenu kormiv").

Використання кормових добавок для виробництва корму можливе лише після вивчення ефективності та безпечності кормових добавок та реєстрації іiї в Україні.

Дослідження ефективності застосування кормових добавок проводиться in vitro та in vivo.

Дослідження ефективності застосування технологічних кормових добавок in vitro $є$ потужним інструментом для виявлення потенційних сорбентів стосовно мікотоксинів.

Якщо досліджуваний продукт не адсорбує мікотоксин in vitro, то у нього мало чи взагалі немає можливості робити це in vivo. Лабораторні методи визначення сорбційної активності кормових добавок- сорбентів можуть бути дуже корисними для визначення та класифікації потенційних мікотоксиндетоксикаційних продуктів, а також для визначення механізмів та умов, сприятливих для адсорбції (Diaz \& Smith, 2005).

Метою нашої роботи на даному етапі було встановлення in vitro ефективності застосування кормової добавки Гепасорбекс шляхом підтвердження ії здатності стримувати або знижувати поглинання мікотоксинів (зокрема афлатоксину $\mathrm{B}_{1}$ ), сприяти їх виведенню чи змінювати спосіб їх дії.

\section{Матеріал і методи досліджень}

Дослідження проведено на базі лабораторії контролю кормових добавок та преміксів Державного науково-дослідного контрольного інституту ветеринарних препаратів та кормових добавок. Для проведення досліджень використовували кормову добавку Гепасорбекс виробництва ТОВ "ВЕТСЕРВІСПРОДУКТ”. Кормова добавка Гепасорбекс являє собою порошок сірого кольору із специфічним запахом. До складу кормової добавки входить бентоніт, сухі пивні дріжджі, розторопша плямиста. Гепасорбекс належить до категорії технологічні добавки. У межах цієї категорії кормову добавку можна віднести до таких функціональних груп речовин для зменшення забруднення кормів мікотоксинами - речовини, здатні стримувати або знижувати поглинання мікотоксинів, сприяти їх виведенню чи змінювати спосіб їх дії.

Згідно 3 вітчизняними рекомендаціями (Kocyumbas et al., 2013) та вимогами Європейського Союзу (Commission regulation (ЕС) № 429, 2008) вивчення ефективності технологічних добавок може проводитися in vitro. Виходячи 3 цього, нами було проведено вивчення ефективності застосування кормової добавки in vitro стосовно вивчення здатності стримувати або знижувати поглинання афлатоксину $\mathrm{B}_{1}$, сприяти його виведенню.

Ефективність кормової добавки щодо адсорбції афлатоксину $\mathrm{B}_{1}$ визначали у відсотках стосовно кількості внесеного (наявного) міктоксину в досліджуваному зразку та кількістю адсорбованого мікотоксину за дії кормової добавки. При цьому враховували умови перебування корму в шлунково-кишковому тракті тварини (кислий у шлунку та нейтрально-лужний у кишечнику).

Практичний коефіцієнт корисної дії (ПККД) визначали шляхом обрахування різниці між кількістю внесеного та зв'язаного мікотоксину з урахуванням різниці між адсорбцією (зв'язуванням) і десорбцією (вивільненням). Чим вищий цей коефіцієнт, тим ефек- 
тивніша дія кормової добавки - тим більша кількість зв'язаного i, тим самим, дезактивованого мікотоксину. Ефективність специфічної дії кормової добавки визначали кількісно при різних $\mathrm{pH}$, що імітують зміну кислотності середовища в травному каналі тварин (Malkov et al., 2012, Lysko, 2013).

Дослідження проводили у два етапи: скринінговий - 3 використанням кормової добавки Гепасорбекс та розчину мікотоксину та основний - з використанням комбікорму, який містив мікотоксин та кормову добавку Гепасорбекс.

На скринінговому етапі використовували у буферні розчини із $\mathrm{pH} 2$, які містили афлатоксин $\mathrm{B}_{1} \mathrm{y}$ кількості 200 мкг/мл (0,02\%). 0,1 г кормової добавки Гепасорбекс поміщали у колби. До колб приливали $10 \mathrm{~cm}^{3}$ буферного розчину, інкубували при постійному перемішуванні (з допомогу магнітної мішалки) 1 годину при температурі $37{ }^{\circ} \mathrm{C}$, відокремлювали надосадову рідину від осаду методом центрифугування і визначали в ній вміст афлатоксину $\mathrm{B}_{1}$ методом ІФА. Після цього вираховували величину адсорбції загальну кількість зв'язаного мікотоксину за різницею між його кількістю у вихідному розчині та у центрифугаті після інкубування.

До осаду додавали $10 \mathrm{~cm}^{3}$ буферу з $\mathrm{pH}$ 7,4, інкубували при постійному перемішуванні (з допомогу магнітної мішалки) 3 години при температурі $37^{\circ} \mathrm{C}$, моделюючи $\mathrm{pH}$ середовища і орієнтовний час перебування корму в кишечнику. Надосадову рідину відокремлювали шляхом центрифугування та досліджували на вміст афлатоксину $\mathrm{B}_{1}$ методом ІФА.

Отримували величину десорбції - кількість токсину, звільненого із кормової добавки після інкубації в лужному середовищі.

На другому етапі в попередньо протестовані корми, які містили афлатоксин $\mathrm{B}_{1}$, вносили досліджувану кормову добавку Гепасорбекс з розрахунку 1, 2, 5 г/кг і ретельно гомогенізували проби.

20 г проби комбікорму поміщали в конічну колбу До колби приливали $40 \mathrm{~cm}^{3}$ буферного розчину, інкубували при постійному перемішуванні (з допомогу магнітної мішалки) 1 годину при температурі $37^{\circ} \mathrm{C}$, відокремлювали надосадову рідину від осаду методом центрифугування і визначали в ній вміст мікотоксинів методом ІФА. Після цього вираховували величину адсорбції.

До осаду додавали $40 \mathrm{~cm}^{3}$ буферу з рН 7,4, інкубували при постійному перемішуванні (з допомогу магнітної мішалки) 3 години при температурі $37^{\circ} \mathrm{C}$, моделюючи $\mathrm{pH}$ середовища і час перебування корму в кишечнику. Надосадову рідину відокремлювали шляхом центрифугування та досліджували на вміст мікотоксинів методом ІФА.

Отримали величину десорбції - кількість токсину, звільненого із кормової добавки після інкубації в лужному середовищі.

Практичний коефіцієнт корисної дії кормової добавки у відсотках стосовно мікотоксинів визначали як різницю між кількістю мікотоксину в досліджуваному зразку та кількістю мікотоксину у надосадовій рідині після інкубації у кислому середовищі з урахуванням кількісті мікотоксину у надосадовій рідині після інкубації в лужному середовищі (Vekiru et al., 2007; Fruhauf et al., 2012; Golovnja, 2014; Levytskyy, 2018).

\section{Результати та їх обговорення}

Результати дослідження на скринінговому етапі дослідження наведені в таблицях. У таблиці 1 наведено результати стосовно адсорбційних властивостей кормової добавки Гепасорбекс стосовно афлатоксину $\mathrm{B}_{1}$.

\section{Таблиця 1}

Адсорбційні властивості кормової добавки Гепасорбекс стосовно афлатоксину $\mathrm{B}_{1}$

\begin{tabular}{ccccc}
\hline $\begin{array}{c}\text { Внесено афлатоксину } \\
\text { В.1, мкг/мл }\end{array}$ & $\begin{array}{c}\text { Адсорбція, } \\
\text { мкг/мл }\end{array}$ & $\begin{array}{c}\text { Десорбція, } \\
\text { мкг/мл }\end{array}$ & $\begin{array}{c}\text { Сумарно адсорбовано } \\
\text { афлатоксину В }, \text { мкг/мл }\end{array}$ & \begin{tabular}{c} 
ПККд, \% \\
\hline 200
\end{tabular} \\
\hline
\end{tabular}

Дані таблиці 1 свідчать, що у кислому середовищі (рН 2) адсорбція афлатоксину $\mathrm{B}_{1}-187$ мкг/л, що становить 93,5\% від внесеного. Після інкубування у слаболужному середовищі концентрація афлатоксину $\mathrm{B}_{1}$ надосадовій рідині становила 8 мкг/л. Враховуючи наведені дані, встановлено, що практичний коефіцієнт корисної дії кормової добавки у скринінговому досліді стосовно афлатоксину $\mathrm{B}_{1}$ становив $89,5 \%$.

Наведені дані свідчать, що кормова добавка Гепасорбекс має виражену здатність адсорбувати афлатоксин $\mathrm{B}_{1}$. Проведені дослідження стосуються лише здатності адсорбувати мікотоксин із модельних розчинів. На величину адсорбції при внесенні кормової добавки у багатокомпонентні кормові суміші можуть впливати різні фактори.

Тому для вивчення практичної ефективності кормової добавки іï вносили у кормову суміш, контаміновану мікотоксинами.

Результати вивчення ефективності застосування кормової добавки внесеної у комбікорми, контаміновані афлатоксином $\mathrm{B}_{1}$, наведено в таблиці 2 .

Дані таблиці 2 свідчать, що внесення кормової добавки Гепасорбекс у комбікорм контамінований афлатоксином $\mathrm{B}_{1}$ сприяло адсорбції значної частини цього мікотоксину. 
Таблиця 2

Адсорбційні властивості кормової добавки Гепасорбексу складі комбікорму стосовно афлатоксину $\mathrm{B}_{1}$

\begin{tabular}{cccccc}
\hline $\begin{array}{c}\text { Внесено кормової } \\
\text { добавки, г/кг }\end{array}$ & $\begin{array}{c}\text { Виявлено афла- } \\
\text { токсину В } \\
\text { бікормі, мг/кг }\end{array}$ & $\begin{array}{c}\text { Адсорбція, } \\
\text { мкг/кг }\end{array}$ & $\begin{array}{c}\text { Десорбція, } \\
\text { мкг/кг }\end{array}$ & $\begin{array}{c}\text { Сумарно адсорбо- } \\
\text { вано афлатоксину } \\
\mathrm{B}_{1}, \text { мкг/кг }\end{array}$ & $\begin{array}{c}\text { ПКкд, } \\
\%\end{array}$ \\
\hline 1 & 0,032 & 0,027 & 0,003 & 0,024 & 75,0 \\
2 & 0,032 & 0,028 & 0,002 & 0,026 & 81,2 \\
5 & 0,032 & 0,030 & 0,003 & 0,027 & 84,4 \\
\hline
\end{tabular}

Внесення кормової добавки Гепасорбекс у комбікорм в кількості 1, 2, 5 г/кг гарантувало адсорбцію у кислому середовищі (рН 2) відповідно 84,4\%, 87,5\%, 93,5\% афлатоксину $\mathrm{B}_{1}$, від кількості яка була підтверджена на початку дослідження. Десорбція у слабо лужному середовищі (pH 7,4) становила 0,020,03 мг/кг, що становить відповідно від 9,3, 6,2 та 9,3\% від внесеного мікотоксину залежно від кількості внесеної кормової добавки. Враховуючи кількість виявленого мікотоксину, величину адсорбції та десорбції, практичний коефіцієнт корисної дії кормової добавки Гепасорбекс у досліді становив при внесенні у дозі 1 г/кг 75,0\%, при внесенні у дозі 2 г/кг - 81,2\%, при внесенні у дозі 5 г/кг -84,4\%.

Отже практичний коефіцієнт корисної дії кормової добавки при внесенні у комбікорм стосовно афлатоксину $\mathrm{B}_{1}$ був в різній мірі, але нижчим ніж при скринінгових дослідженнях. Це, очевидно, пов'язано з тим, що кормові суміші містять моно- і дисахариди, жирні кислоти, тригліцериди, неорганічні солі і ін., які в певній мірі реагують 3 кормовою добавкою, знижуючи іiі ефективність стосовно мікотоксинів (Levytskyy, 2018). Однак, незважаючи на це, практичний коефіцієнт корисної дії стосовно афлатоксину $\mathrm{B}_{1}$ був досить високим.

Високу ефективність кормових добавок, які містять в якості діючої речовини бентоніти та клітинні стінки дріжджів відмічається і іншими дослідниками. Так, при дослідження ефективності застосування бентонітів різного походження методом in vitro Kong C. встановив, що відсоток адсорбції стосовно афлатоксину $B_{1}$ становив 80,9-99,2\% в залежності від природи бентоніту. Адсорбція афлатоксину при застосуванні клітинних стінок дріжджів становила 92,7\% (Kong et al., 2014). Дослідження бентонітів різного походження, проведені різними авторами підтверджують їх високу адсорбційну здатність стосовно афлатоксинів (Thieu et al., 2008, Pappas et al., 2014). Тенденцію до нижчого рівня адсорбції мікотоксинів, і зокрема афлатоксину $\mathrm{B}_{1}$, сорбентами на основі бентонітів при внесенні у корм в порівнянні 3 чистими розчинами мікотоксинів відмічають і інші автори (Malkov et al., 2012; Golovnja, 2014).

\section{Висновки}

В результаті проведених досліджень встановлено, що кормова добавка Гепасорбекс володіє вираженими адсорбційними властивостями стосовно афлатоксину $\mathrm{B}_{1}$. Практичний коефіцієнт корисної дії кормової добавки Гепасорбекс у скринінговому досліді стосовно становив 89,0\%. Практичний коефіцієнт корисної дії кормової добавки Гепасорбекс при внесенні у кормові суміші у різних дозах стосовно афлатоксину $\mathrm{B}_{1}$ становив $69,0-74,8 \%$.

\section{References}

Commission Regulation (EC) № 429/2008 of 25 April 2008 on detailed rules for the implementation of Regulation (EC) No 1831/2003 of the European Parliament and of the Council as regards the preparation and the presentation of applications and the assessment and the authorisation of feed additives (Official Journal of the European Union L 133, 22.5.2008. P. 60). https://publications.europa.eu/en/publication-detail//publication/0f3c96bf-3c8a-4a00-95dab1e85a4cb6bb/language-en.

Diaz, D.E., \& Smith, T.K. (2005). Mycotoxin Sequestering Agents: Practical Tools for the Neutralization of Mycotoxins. The Mycotoxin Blue Book.

Fruhauf, S., Schwartz, H., Ottner, F., Krska, R., \& Vekiru, E. (2012). Yeast cell based feed additives: studies on aflatoxin $\mathrm{B}_{1}$ and zearalenone. Food Additives and Contaminants, 29(2), 217-231. doi: 10.1080/19440049.2011.630679.

Golovnja, E. (2014). Nuzhno li ocenivat' jeffektivnost' sorbentov. Kombikorma, 4, 67-68 ( in Russian)

Kocyumbas, I.Ya., Bisyuk, I.Yu., Gorzheyev, V.M., \& Maly`k, O.G. (2013). Klinichni doslidzhennya vetery'narny`h preparativ ta kormovy`h dobavok. L`viv (in Ukrainian).

Kong, C., Shin, Y., \& Gyun, B.K. (2014). Evaluation of mycotoxin sequestering agents for aflatoxin and deoxynivalenol: an in vitro approach. SpringerPlus, 3, 346. doi: 10.1186/2193-1801-3-346.

Levytskyy, T.R. (2018). Efficiency of use technological feed additive. Scientific Messenger of Lviv National University of Veterinary Medicine and Biotechnologies, 20(84), 143-147. doi: 10.15421/nvlvet8426.

Lysko, S.B. (2013). Sorbcionnaja aktivnost' novogo sorbenta prirodnogo proishozhdenija $\mathrm{v}$ otnoshenii T-2 toksina. Veterinarija i kormlenie, 6, 28-29 (in Russian).

Malkov, M.A., Bogomolov, V.V., Dan'kova, T.V., \& Krasnov, K.A. (2012). Mikotoksiny - strategija ustranenija ih vlijanija na organizm sel'skohozjajstvennyh zhivotnyh i pticy. Cenovik, 1, 74-75 (in Russian).

Pappas, A.C. Tsiplakou, E., Georgiadou, M., Anagnostopoulos, C., Markoglou, A.N., Liapis, K., \& Zervas, G. (2014). Bentonite binders in the presence of mycotoxins: Results of in vitro preliminary tests 
and an in vivo broiler trial. Applied Clay Science, 99, 48-53. doi: 10.1016/j.clay.2014.06.009.

Thieu, N., \& Pettersson, H. (2008). In vitro evaluation of the capacity of zeolite and bentonite to adsorb aflatoxin $\mathrm{B} 1$ in simulated gastrointestinal fluids. Mycotoxin Research, 24(3), 124-129. doi: 10.1007/BF03032338.
Vekiru, E., Fruhauf, S., Sahin, M., Ottner, F., Schatzmayr, G., \& Krska, R. (2007). Investigation of various adsorbents for their ability to bind Aflatoxin $\mathrm{B}_{1}$ Mycotoxin Research, 23(1), 27-33. doi: 10.1007/BF02946021.

Zakon Ukrayiny' "Pro bezpeku ta gigiyenu kormiv", Golos Ukrayiny”, № 12, 19.01.2018 (in Ukrainian). 